\title{
Factors Influencing Intranet Acceptance in Restaurant Industry: Use of Technology Acceptance Model
}

\author{
Kunsoon Park ${ }^{1}$, Narang Park $^{2}$, Wookjae, Heo ${ }^{1}$ \\ ${ }^{1}$ Department of Consumer Sciences, College of Education and Human Sciences, South Dakota State University, \\ Brookings, SD, USA \\ ${ }^{2}$ Department of Financial Planning, Housing, and Consumer Economics, College of Family and Consumer \\ Sciences, University of Georgia, Athens, GA, USA \\ Correspondence: Narang Park, Department of Financial Planning, Housing, and Consumer Economics, College \\ of Family and Consumer Sciences, University of Georgia, Athens, GA 30602, USA.
}

Received: August 13, 2018

Accepted: September 1, $2018 \quad$ Online Published: September 20, 2018

doi:10.5539/ibr.v11n10p1

URL: https://doi.org/10.5539/ibr.v11n10p1

\begin{abstract}
This study examines factors influencing the user acceptance of intranets in the restaurant industry. The study uses the application of the technology acceptance model (TAM) in explaining intranet usage in restaurant operations. The TAM is an exceptional model for which to predict system usage and has been successfully applied to numerous technologies. The original model was modified to include two independent variables: organization support and information quality. The survey collected data from restaurants in the United States. The results of the study showed that perceived usefulness was the main factor influencing intranet acceptance, while organization support, information quality, and perceived ease of use were not significant in the regression analysis. The findings indicate perceived usefulness of intranet use requires focus in order to improve communications in restaurant franchise systems.
\end{abstract}

Keywords: intranet, perceived usefulness, restaurant, TAM

\section{Introduction}

According to a recent report, restaurant industry sales reached $\$ 799$ billion in 2017, and, among the restaurants, $35 \%$ were found to be franchised (Thompson, 2018). As the statistics indicate, the franchise system is prevalent in the restaurant industry. Similar to other franchise industries, restaurant franchises are always facing challenges, such as launching new products, adjusting merchandise structures, and developing private branding strategies, in response to diverse consumer demands (Lee, Hsu, \& Huang, 2008). To implement all the new projects and to deal with customer feedback, franchisors and franchisees require prompt communication. Communication not only helps franchisors to make managerial efforts to stimulate positive attitudes among franchisees but also to enhance franchisees' loyalty to the franchise system (Lee et al., 2008). As a result of the positive function of communication in a franchise system, companies are typically able to devise effective communication channels.

Restaurant franchise companies have also sought a more sophisticated means of communication, along with intranet systems designed specifically to suit their needs (Repack \& Repack, 2010). Communication is challenging in an environment where contact with several restaurants on a daily basis is required. Thus, the intranet has been introduced as faster, more efficient means of communication within the restaurant industry as opposed to using telephones, fax machines, and the postal service (Esterson, 1998). A restaurant franchise company's intranet becomes a primary resource whenever it is needed for information on training, marketing materials, and operations manuals (Fisher, 2002; Foley, 2005).

Simple and effective models have been developed for explaining the success of many information and communication technology tools. However, little attention has been given toward developing a widely accepted model of intranet acceptance. The widely used technology acceptance model (TAM) is applied to the current study of intranet use in restaurant operations. This study is concerned with system usage, which is not the same as system success but is necessary. Previous studies frequently adopt usage as a measure of success (Szajna, 1993); others have used alternative measures of success, e.g., user satisfaction (Miller \& Doyle, 1987; McKeen, Guimeraes, \& Wetherbe, 1994). The concept of success will have a different meaning to each organization in 
which an intranet is being developed. System usage is an important issue to all as an element of success. The appropriate level of system usage is seen as a basis toward acquiring the benefits expected from an intranet.

\section{Literature Review}

A franchised business is, by nature, a geographically dispersed organization; therefore, communication can easily become a barrier against efficiency and the quality of service provided (Grunber, 1997). Lee, Hsu, and Huang (2008) showed how communication plays an important role in the franchise system. The authors found that collaborative communication determined the relationship between franchisors and franchisees. Collaborative communication in the franchise system was not only positively associated with franchisees' satisfaction with economic outputs but also satisfaction with social interactions with the franchisors. These satisfactions consequently related to the higher intention to renew a franchise contract. In addition, satisfied franchisees exhibited a higher willingness to recommend a system to others. Thus, improving the flow of information between the franchisor and franchisees is key to a franchise system's future.

Information technology (IT) has permanently changed the methods businesses use to communicate (Meuter, Bitner, Ostrom, \& Brown, 2005). Communication between franchisors and franchisees via the system-wide network, i.e., the intranet, is perhaps the most basic technology tool used extensively by franchise systems (Larson, 2002; Saleh \& Kleiner, 2005). An intranet is a private corporate network secured from public access and is only accessible via organizational members. Many franchisors use an intranet to transfer data, share confidential information, and facilitate discussions (Stefanović \& Stanković, 2014). As franchisees are typically remote from headquarters, these activities (i.e., sharing information) are used to require a considerable operating cost in the past. However, an intranet replaces numerous brochures, letters, and notes; thus, it reduces associated costs for producing and delivering information (Stefanović \& Stanković, 2014). Moreover, an intranet for a franchise system enables users to store information easily, access resources instantly, keep documents current, save time, and maintain their networks inexpensively.

Both franchisors and franchisees benefit from the ability to instantly locate information or network with other franchisees via intranet systems. Franchise systems that have implemented intranet systems have done so in order to enhance communications and support for their franchisees. Franchisors thus became able to collect financial information or monthly reports from franchisees in a timely manner. They have adapted the intranet to accommodate franchisees' actual needs in the real world (Martin, 1999). Consequently, franchisors establish better business strategies and provide support promptly. Franchisors also face challenges in managing franchise units when the franchise system becomes bigger. Further, the intranet is a useful tool for monitoring the system. Stefanović and Stanković (2014) found the use of information technology in a franchise system, and the number of franchise units were positively related. This implies that the connectedness through an intranet increases efficiency and control within the franchise system.

Franchisees also rely on the intranet for day-to-day support and ease for resource access (Bevis, 2005). Further, an intranet is easy to utilize, and it helps a franchise to better run its business. Empirically, Iyengar, Sweeney, and Montealegre (2015) found that the use of information technology acted as an important learning mechanism for franchisees, which eventually enhances a firms' financial growth. Using a comprehensive data set obtained from 783 franchises, the researchers discovered that knowledge effectively transferred through internal information technology had a significant impact on franchisees' absorptive capability-defined as "the ability to recognize, assimilate, and apply knowledge" (Iyengar, Sweeney, \& Montealegre, 2015, p. 623). Absorptive capability is an important concept in a business performance. It refers to a firm's ability to recognize the potential value of new knowledge, link the new knowledge to the franchisees' localized conditions, and apply it to their existing competencies for improvement (Iyengar et al., 2015) Thus, the higher absorptive capability the franchisees have, the better performances they are likely to achieve (Roberts, Galluch, Dinger, \& Grover, 2012). In Iyengar and his fellows' study, the use of internal IT had no direct effect on a firm's financial growth but had an indirect effect mediated by absorptive capacity. In short, franchisees can benefit from the support transferred through information technology (i.e., intranet) to reinforce their business performance.

Previous researchers noted information quality does matter when conducting studies regarding information technology (Gorla, Somers, \& Wong, 2010; Wahdain \& Ahmad, 2014; Zheng, Zhao, \& Stylianou, 2013). Information quality is defined as "an individual's evaluation of the system's performance in providing information" (Zheng et al., 2013, p. 516). Gorla, Somers, and Wong (2010) claimed that information quality has two dimensions: content and format. Content refers to the relevance of the information, while format indicates the style of presentation. In short, the quality of information should be relevant, accurate, concise, consistent, and understandable (Al-Mamary, Shamsuddin, \& Abdul Hamid, 2014; Gorla et al., 2010). Users consider 
information technology less useful if the information quality does not match the value they seek. Researchers found that the users' perception of information quality had a positive association with the intention to use technology (Calisir, Altin Gumussoy, Bayraktaroglu, \& Karaali, 2014; Zheng et al., 2013) and organizational performances (Al-Mamary et al., 2014). Thus, it is reasonable to think that the use of an intranet for a franchise system would increase when the information transferred through the technology is perceived as being helpful.

Organizational support is also a significant factor for information technology usage. Bhattacherjee and Hikmet (2008) found organizational support motivated organizational members' intention to use information technology. According to their analysis, organizational commitment to support end users (i.e., infrastructural, technical) increased the users' perceived ease of use, which ultimately enhanced the perception of usefulness, favorable attitudes toward information technology, and intention to use. Similar results were found from studies about restaurant employees' intention to use information technology (Ham, Kim, \& Forsythe, 2008; Park, Lee, \& Khan, 2014). In a restaurant franchise system, franchisees' intranet usage could be encouraged by franchisors' technical and emotional support.

\section{Theoretical Framework}

The base theory for this research on intranet acceptance is the TAM developed by Davis (1989). Davis (1989) demonstrated that TAM can explain the usage of information technology. He applied Ajzen and Fishbein's (1980) theory about reasoned action to illustrate that beliefs influence attitudes that, in turn, lead to intentions and therefore generate behaviors. Davis (1989) thus conceived that TAM's belief-attitude-intention-behavior relationship predicts user acceptance of information technology. He further asserted that perceived usefulness and ease of use represent the beliefs that lead to such acceptance. Perceived usefulness is the degree to which a person believes a particular information system would enhance his or her job performance (i.e., by reducing the time to accomplish a task or by providing timely information). Perceived ease of use is the degree to which a person believes that using a particular system would be effortless (Davis, 1989). Two other constructs in TAM are attitude toward use and behavioral intentions to use. Attitude toward use is the user's evaluation of the desirability of employing a particular information system's application. Behavioral intention to use is a measure of the likelihood a person will employ the application (Ajzen \& Fishbein, 1980). TAM's dependent variable is actual usage, which has typically been a self-reported measure of time or frequency of employing the application.

TAM has been explored frequently in the use of technology acceptance and has been modified in order to investigate external factors that affect user acceptance in a variety of industry sections, including the hospitality and tourism industry (Ham et al., 2008; Kaplanidou \& Vogt, 2006; Kim, Lee, \& Law, 2008; Lam, Cho, \& Qu, 2007; Lee, Kim, \& Lee, 2006; Luo, Remus, \& Sheldon, 2007). In spite of the growing IT adoption rate in hospitality firms, limited research has been accomplished for hospitality and tourism companies. The use of technology in restaurant operations has been less researched than other hospitality sectors (Ham et al., 2008).

\section{Research Model and Hypotheses}

The objective of this paper is to test the suitability of TAM for modeling an intranet use through testing four hypotheses. Based on the literature review, a model indicating the acceptance of an intranet was developed (Figure 1). The model consists of four factors that have an effect on acceptance of an intranet.

Organization support refers to the perceived level of general support offered by top management in organizations (Igbaria, 1993). Organization support ensures sufficient allocation of resources and acts as a change agent to create a more conductive environment for information systems success (Igbaria, 1993; Konradt, Christophersen, \& Schaeffer-Kuelz, 2006). Therefore, organization support is associated with greater system success, while lack of it is considered a critical barrier to the effective utilization of information technology (Abdul-Gader, 1992; DeLone, 1988; Yap, Soh, Raman, 1992). Organization support influences system usage in organizations (Cerveny \& Sanders, 1986; Lucas, 1981).

Information quality refers to the desirable characteristics of the system outputs (DeLone \& McLean, 2003). Information quality is related to useful system output (Kutlu \& Alkaya, 2015; Sirsat \& Sirsat, 2016). Information quality also includes the ability to acquire information that is sufficient to meet end-user needs (Reeves \& Bednar, 1994). Information quality is related to system use (Fitzgerald \& Russo, 2005; Rai, Lang, \& Welker, 2002).

Perceived usefulness is defined as the degree to which an individual believes that a target system will enhance his or her job performance (Davis, Bagozzi, \& Warshaw, 1989). Perceived usefulness has also been confirmed as 
an important factor that influences user technology acceptance (Gefen \& Straub, 1997; Hsu \& Lu, 2004; Venkatesh \& Davis, 2000).

Perceived ease of use refers to the degree to which an individual believes that using a particular system would be effortless (Davis, 1989). Perceived ease of use further indicates the individual's perception concerning the amount of effort required to use the system (Horton, Buck, Waterson, \& Clegg, 2001; Phelps \& Mok, 1999).

H1. Organization support has a positive effect on user acceptance of an intranet.

H2. Information quality has a positive effect on user acceptance of an intranet.

H3. Perceived usefulness has a positive effect on user acceptance of an intranet.

H4. Perceived ease of use has a positive effect on user acceptance of an intranet.

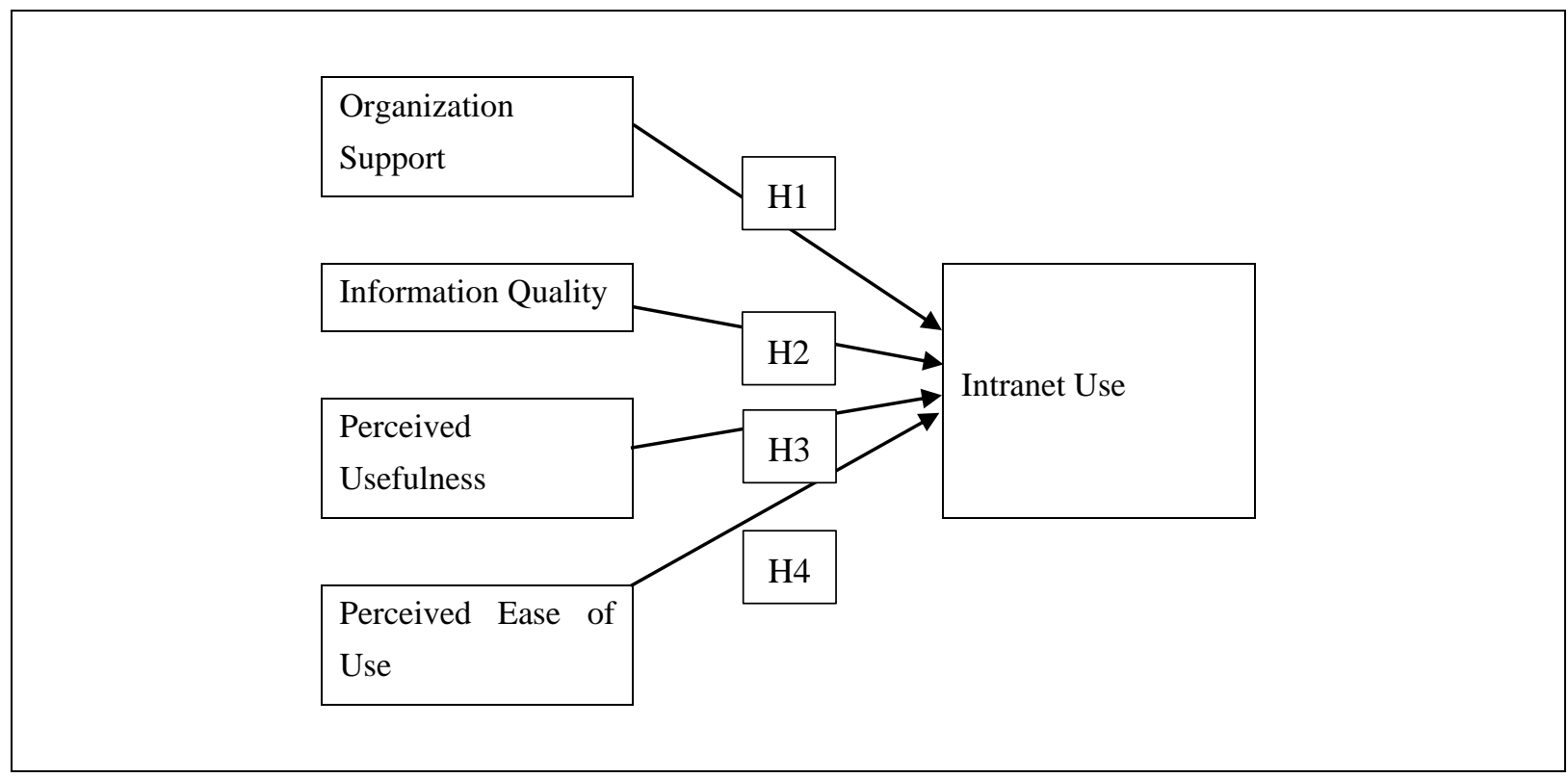

Figure 1. The Research Model

\section{Method}

Data for the study were collected via survey. The questionnaire includes five measures: organization support (Igbaria, 1993), information quality (Lederer, Maupin, Sena, \& Zhuang, 2000), perceived usefulness of an intranet (Davis, 1989; Davis et al., 1989), perceived ease of use of an intranet (Davis, 1989; Davis et al., 1989), and actual use of an intranet (Ajzen \& Fishbein, 1980). The questions were modified for this study by substituting "intranet" for the specific system examined in previous studies. Five-point scales were used for all of the aforementioned constructs' measurement, with 1 being "strongly disagree" and 5 being "strongly agree." The questionnaire was revised based on feedback received from the pilot test. A total of 169 questionnaires were returned, but 161 were used for data analysis after eliminating eight due to partial completion.

\section{Results}

Study respondents were those individuals who use an intranet for tasks in restaurant franchise systems in the United States. The majority of respondents were male (76.40\%). Most of the respondents $(94.40 \%)$ attended some college; $47.50 \%$ of the respondents used an intranet several times each day; and $17.70 \%$ used it about once a day. On average, respondents were 44.28 years old, used an intranet 9.02 hours per week, and worked nine years, using an intranet system 3.97 years for their current franchise.

A factor analysis was conducted using principal axis factoring with varimax rotation as an extraction method. Five variables did not fit into the factor model. One of the variables excluded was associated with information quality, two with perceived usefulness, and two with perceived ease of use. The four factors identified were chosen in terms of eigenvalues larger than 1.0. The Bartlett's test of sphericity confirmed that the variables within factors are correlated. The Kaiser-Meyer-Olkin (KMO) measure of sampling adequacy indicated a practical level of common variance $(\mathrm{KMO}=0.929)$. Thereby, the factor analysis was appropriate. The identified factors (Table 1) represent $70.38 \%$ of the variance of the variables. The first factor, organization support (OS), consisted of five variables $($ alpha $=0.89$ ). The second factor, information quality $(\mathrm{IQ})$, was loaded with 10 variables (alpha $=0.96)$. The third factor, perceived usefulness $(\mathrm{PU})$, contained eight variables (alpha $=0.96)$. 
The fourth factor referred to perceived ease of use (PEU) and was loaded with six variables (alpha $=0.90$ ).

Table 1. Results of Factor Analysis

\begin{tabular}{|c|c|c|c|c|}
\hline \multirow[b]{2}{*}{ Variables } & \multicolumn{4}{|c|}{ Factor } \\
\hline & OS & IQ & PU & PEU \\
\hline $\begin{array}{l}\text { I am convinced that franchisor is sure of the benefits which can be achieved } \\
\text { with the use of the intranet. }\end{array}$ & 0.767 & & & \\
\hline $\begin{array}{l}\text { I am always supported and encouraged by my franchisor to use the intranet in } \\
\text { my job. }\end{array}$ & 0.744 & & & \\
\hline Franchisor is eager to see that franchisees are happy with using the intranet. & 0.706 & & & \\
\hline $\begin{array}{l}\text { Franchisor has provided most of the necessary help and resources to get } \\
\text { franchisees used to the intranet quickly. }\end{array}$ & 0.693 & & & \\
\hline $\begin{array}{l}\text { Franchisor is available to help whenever I have any trouble with the intranet } \\
\text { use. }\end{array}$ & 0.662 & & & \\
\hline The information on the intranet is effective. & & 0.838 & & \\
\hline Sufficient detailed information is maintained on the intranet. & & 0.825 & & \\
\hline The information on the intranet is efficient. & & 0.795 & & \\
\hline The information on the intranet is reliable. & & 0.792 & & \\
\hline The information on the intranet is up-do-date enough for my purposes. & & 0.787 & & \\
\hline The intranet adequately meets my information needs. & & 0.766 & & \\
\hline $\begin{array}{l}\text { The intranet maintains information at an appropriate level of detail for my } \\
\text { task. }\end{array}$ & & 0.745 & & \\
\hline The information on the intranet is current enough to meet my needs. & & 0.726 & & \\
\hline The information on the intranet is accurate. & & 0.722 & & \\
\hline $\begin{array}{l}\text { The information on the intranet is pretty much what I need to carry out my } \\
\text { tasks. }\end{array}$ & & 0.686 & & \\
\hline Using the intranet in my job increases my productivity. & & & 0.869 & \\
\hline Using the intranet enhances my effectiveness on the job. & & & 0.843 & \\
\hline Using the intranet makes it easier to do my job. & & & 0.832 & \\
\hline Using the intranet improves my job performance & & & 0.802 & \\
\hline Using the intranet in my job enables me to accomplish tasks more quickly. & & & 0.778 & \\
\hline I find the intranet to be useful in my job. & & & 0.749 & \\
\hline $\begin{array}{l}\text { I can better take advantage of the services provided by the franchisor by using } \\
\text { the intranet. }\end{array}$ & & & 0.648 & \\
\hline Using the intranet is helpful in conducting day-to-day business. & & & 0.646 & \\
\hline It was easy for me to become skillful at using the intranet. & & & & 0.881 \\
\hline My interaction with the intranet is clear and understandable. & & & & 0.820 \\
\hline I find the intranet easy to use. & & & & 0.805 \\
\hline Learning to operate the intranet was easy for me. & & & & 0.734 \\
\hline I find it easy to get the intranet to do what I want it to do. & & & & 0.680 \\
\hline I find the intranet to be flexible enough to interact with. & & & & 0.645 \\
\hline Eigenvalue & 18.823 & 3.758 & 2.615 & 1.549 \\
\hline Percentage of total variance explained & 49.533 & 9.890 & 6.882 & 4.075 \\
\hline
\end{tabular}

Notes. Organization support (OS), Information quality (IQ), Perceived usefulness (PU), Perceived ease of use (PEU)

This factor model was then used to analyze use of an intranet. The dependent variable was formed by summing up actual use of an intranet. This was done, as it gives a better view of the use of an intranet with the data used. Regression analysis was conducted to reveal how different factors affect the use of an intranet. Although of the explanatory variables and their coefficients, only perceived usefulness $(t=8.00 ; p<0.001)$ is statistically significant, and the overall model was statistically significant $\left(R^{2}=0.583 ; p<0.001\right)$. Results of the regression analysis are presented in Table 2 . 
Table 2. Results of Regression Analysis

\begin{tabular}{lccccc}
\hline Model summary & $R$ & $R^{2}$ & Adjusted $R^{2}$ & \multicolumn{2}{c}{ Std error of the estimate } \\
\hline Model & $0.764^{\mathrm{a}}$ & 0.583 & 0.571 & \multicolumn{2}{c}{0.642} \\
\hline ANOVA model $^{b}$ & $S S$ & $d f$ & $M S$ & $F$ & Sig. \\
Regression & 81.798 & 4 & 20.450 & 49.644 & $0.000^{\mathrm{b}}$ \\
Residual & 58.494 & 142 & & & \\
Total & 140.292 & 146 & & & \\
\hline Coefficients $^{\mathrm{a}}$ & $\mathrm{B}$ & Std. error & Beta & 1.053 & Sig. \\
(Constant) $_{\text {Organization support }}$ & 0.364 & 0.346 & & 0.294 \\
Information quality & 0.084 & 0.079 & 0.086 & 1.065 & 0.289 \\
Perceived usefulness & 0.103 & 0.098 & 0.081 & 1.054 & 0.294 \\
Perceived ease of use & 0.584 & 0.073 & 0.617 & 8.000 & 0.000 \\
\hline
\end{tabular}

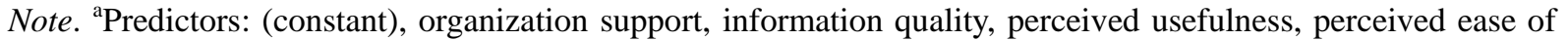
use. ${ }^{\mathrm{b}}$ Dependent variable: actual use

A correlation analysis was run to further test the hypotheses. The results indicate that OS, IQ, PU, and PEU are positively correlated with use $(p<0.001)$. Correlations of all factors with use of an intranet are displayed in Table 3. In sum, all factors have a positive effect on the use of an intranet. Based on data analysis, it seems that OS, IQ, PU, and PEU are statistically significant. This means that $H 1, H 2, H 3$, and $H 4$ were supported by the data.

Table 3. Results of Correlation Analysis

\begin{tabular}{lcccc}
\hline & Organization support & Information quality & Perceived usefulness & \multicolumn{2}{c}{ Perceived ease of } \\
use
\end{tabular}

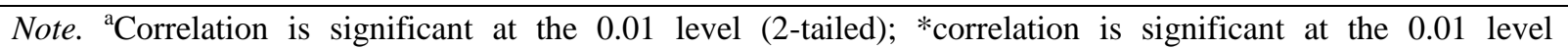
(two-tailed)

\section{Conclusion}

The primary objective of the study was to study user acceptance of an intranet in the light of the technology acceptance model (TAM) added with new variables. The new model proposed that intranet acceptance can be modeled with the variables derived from the TAM (PU and PEU) and two other variables referring to organization support (OS) and information quality (IQ). In the results section, the model was tested with 161 users and revised. With the use of a factor analysis, four factors were identified suggesting that OS, IQ, PU, and PEU have an impact on the acceptance of an intranet.

The results of regression analysis conducted on the four factors indicate that PU was found to be among the most influential factors explaining the use of an intranet. This finding refers to the fact that users use an intranet for the benefits it provides in comparison with other communication channels. This finding is parallel with other TAM studies (e.g., Davis, 1989; Davis et al., 1989), which found that PEU has less impact on technology acceptance than PU. Perceived ease of use either had only an indirect effect mediated by perceived usefulness (Bhattacherjee \& Hikmet, 2008; Ham et al., 2008) or had no effect (Calisir et al., 2014), while perceived usefulness always had a direct effect on information technology (IT) usage. Bhattacherjee and Hikmet (2008) provided a plausible explanation for this, i.e., people may disregard emotional barriers if they think the given IT is truly expected to be useful for work performance. Zheng, Zhao, and Stylianou (2013) also excluded perceived ease of use in their model, as they viewed that perceived ease of use would be less meaningful in predicting future use because an individual grows accustomed to a system as he or she accumulates the experience of using it. This implies that people are no longer feeling it is difficult to use information technology. As technology usage becomes more common in modern life, there will be less reluctance to learn new information technology. Thus, perceived ease of use may not remain an issue if one considers the technology is useful. This may be one reason that perceived ease of use was not significant in the regression analysis of this study.

This study contributes to the restaurant intranet literature by providing insights into the factors that may affect intranet acceptance. Organizational support for guidance in intranet may foster higher intranet use. In other 
words, additional assistance programs offered by restaurants have positive influence on user acceptance of an intranet. The quality of information provided by the intranet is an important factor in leading user to accept the intranet. The intranet that provides higher quality of information would results in greater intranet use. The results indicate that its benefits are a critical factor that influences acceptance. Furthermore, PU was more influential than PEU in explaining technology acceptance. This suggests that restaurants should emphasize the benefits of using the intranet. The intranet developers should address usefulness as an important factor when developing intranets.

Although the results can be considered statistically significant in most parts, the study has limitations that affect the reliability and validity of the findings. TAM studies have found that PU and PEU are not the only predictors of technology acceptance. The basis of the model, with OS and IQ as additional variables, still might suffer from the fact that other possible factors influencing the acceptance of using an intranet were not included in the model. The second limitation concerns the sample. Although multiple attempts were made to increase the sample size, it was not large compared with the sample size of other TAM studies and consisted of fast food restaurants only. This has an effect on the generalization of the findings. These limitations pave the way for future studies. Another interesting avenue for further research could be a filtering out those who are required to use an intranet. Some use an intranet may be required, although OS, IQ, PU, and PEU might be low.

\section{References}

Abdul-Gader, A. H. (1992). End-user computing success factors: Further evidence from a developing nation. Journal of End User Computing, 4(3), 4-13. https://doi.org/10.4018/joeuc.1992070101

Ajzen, I., \& Fishbein, M. (1980). Understanding attitudes and predicting social behavior. Englewood Cliffs, NJ: Prentice Hall.

Al-Mamary, Y. H., Shamsuddin, A., \& Abdul Hamid, N. A. (2014). The relationship between system quality, information quality, and organizational performance. International Journal of Knowledge and Research in Management \& E-Commerce, 4(3), 7-10.

Bevis, J. (2005). Smart growth strategies for franchise expansion. Franchising World, 37(1), 76-78.

Bhattacherjee, A., \& Hikmet, N. (2008). Reconceptualizing organizational support and its effect on information technology usage: Evidence from the health care sector. Journal of Computer Information Systems, 48(4), 69-76.

Calisir, F., Altin Gumussoy, C., Bayraktaroglu, A. E., \& Karaali, D. (2014). Predicting the intention to use a web - based learning system: Perceived content quality, anxiety, perceived system quality, image, and the technology acceptance model. Human Factors and Ergonomics in Manufacturing \& Service Industries, 24(5), 515-531. https://doi.org/10.1002/hfm.20548

Cerveny, R. P., \& Sanders, G. L. (1986). Implementation and structural variables. Information and Management, 11(4), 191-198. https://doi.org/10.1016/0378-7206(86)90004-2

Davis, F. D. (1989). Perceived usefulness, perceived ease of use, and user acceptance of information technology. MIS Quarterly, 13(3), 319-340. https://doi.org/10.2307/249008

Davis, F. D., Bagozzi, R. P., \& Warshaw, P. R. (1989). User acceptance of computer technology: A comparison of two theoretical model. Management Science, 35(8), 982-1003. https://doi.org/10.1287/mnsc.35.8.982

DeLone, W. H. (1988). Determinants of success for computer usage in small business. MIS Quarterly, 12(1), 51-61. https://doi.org/10.2307/248803

DeLone, W. H., \& McLean, E. R. (2003). The DeLone and McLean model of information system success: A ten-year update. Journal of Management Information Systems, 19(4), 9-30. https://doi.org/10.1080/07421222.2003.11045748

Esterson, E. (1998). Inner beauties. Inc. Tech, 20(4), 78-90.

Fisher, L. (2002). Getting the most out of system suppliers? Franchising World, 34(4), 48-50.

Fitzgerald, G., \& Russo, N. L. (2005). The turnaround of the London Ambulance Service Computer-Aided Despatch system (LASCAD). European Journal of Information Systems, 14(3), 244-257. https://doi.org/10.1057/palgrave.ejis.3000541

Foley, T. (2005). Supporting international operations through technology. Franchising World, 37(2), 38-40.

Gefen, D., \& Straub, D. W. (1997). Gender differences in the perception and use of e-mail: an extension to the 
technology acceptance model. MIS Quarterly, 21(4), 389-400. https://doi.org/10.2307/249720

Gorla, N., Somers, T. M., \& Wong, B. (2010). Organizational impact of system quality, information quality, and service quality. The Journal of Strategic Information Systems, 19(3), 207-228. https://doi.org/10.1016/j.jsis.2010.05.001

Grunber, D. B. (1997). Intranets and franchising. Franchising World, 29(3), 45.

Ham, S., Kim, W. G., \& Forsythe, H. W. (2008). Restaurant employees' technology use intention: Validating technology acceptance model with external factors. Journal of Hospitality \& Leisure Marketing, 17(1-2), 78-98. https://doi.org/10.1080/10507050801978422

Horton, R. P., Buck, T., Waterson, P. E., \& Clegg, C. W. (2001). Explaining intranet use with the technology acceptance model. Journal of Information Technology, 16(4), 237-249. https://doi.org/10.1080/02683960110102407

Hsu, C. L., \& Lu, H. P. (2004). Why do people play on-line games? An extended TAM with social influences and flow experience. Information and Management, 41(7), 853-868. https://doi.org/10.1016/j.im.2003.08.014

Igbaria, M. (1993). User acceptance of microcomputer technology: An empirical test. Omega, 21(1), 73-90. https://doi.org/10.1016/0305-0483(93)90040-R

Iyengar, K., Sweeney, J. R., \& Montealegre, R. (2015). Information technology use as a learning mechanism: The impact of IT use on knowledge transfer effectiveness, absorptive capacity, and franchisee performance. MIS Quarterly, 39(3), 615-641. https://doi.org/10.25300/MISQ/2015/39.3.05

Kaplanidou, K., \& Vogt, C. (2006). A structural analysis of destination travel intentions as a function of web site feature. Journal of Travel Research, 45(2), 204-216. https://doi.org/10.1177/0047287506291599

Kim, T. G., Lee, J. H., \& Law, R. (2008). An empirical examination of the acceptance behavior of hotel front office systems: An extended technology acceptance model. Tourism Management, 29(3), 500-513. https://doi.org/10.1016/j.tourman.2007.05.016

Konradt, U., Christophersen, T., \& Schaeffer-Kuelz, U. (2006). Predicting user satisfaction, strain and system usage of employee self-services. International Journal of Human-Computer Studies, 64(11), 1141-1153. https://doi.org/10.1016/j.ijhcs.2006.07.001

Kutlu, B., \& Alkaya, A. (2015). Measuring the DeLone and McLean model of information systems success applied to banking sector of turkey. International Journal of Advanced Computational Engineering and Networking, 3(8), 8-13.

Lam, T., Cho, V., \& Qu, H. (2007). A study of hotel employee behavioral intentions towards adoption of information technology. International Journal of Hospitality Management, 26(1), 49-65. https://doi.org/10.1016/j.ijhm.2005.09.002

Larson, P. (2002). Technology 2002: promises and challenges. Franchising World, 34(5), 6-8.

Lederer, A. L., Maupin, D. J., Sena, M. P., \& Zhuang, Y. (2000). The technology acceptance model and the World Wide Web. Decision Support Systems, 29(3), 269-282. https://doi.org/10.1016/S0167-9236(00)00076-2

Lee, H. Y., Kim, W. G., \& Lee, Y. K. (2006). Testing the determinants of computerized reservation system users' intention to use via a structural equation model. Journal of Hospitality \& Tourism Research, 30(2), 246-266. https://doi.org/10.1177/1096348005285087

Lee, K. Y., Hsu, Y. C., \& Huang, H. L. (2008). The impact of communication on satisfaction and loyalty in the franchise system: subjective viewpoints of franchisees. European Retail Research, 22, 117-136. https://doi.org/10.1007/978-3-8349-8099-1_6

Lucas, H. C. (1981). Implementation: The key to successful information systems. New York, NY: McGraw Hill.

Luo, M. M., Remus, W., \& Sheldon, P. J. (2007). Technology acceptance of the lonely planet website: An exploratory study. Journal of Information Technology and Tourism, 9(2), 67-78. https://doi.org/10.3727/109830507781367429

Martin, D. (1999). "Real World" internet applications (that franchise companies actually use. Franchising World, 31(4), 22-26.

McKeen, J. D., Guimeraes, T., \& Wetherbe, J. C. (1994). The relationship between user participation and user satisfaction: An investigation of four contingency factors. MIS Quarterly, 18(4), 427-451. 
https://doi.org/10.2307/249523

Meuter, M., Bitner, M., Ostrom, A., \& Brown, S. (2005). Choosing among alternative service delivery modes: An investigation of customer trial of self-service technologies. Journal of Marketing, 69(2), 61-83. https://doi.org/10.1509/jmkg.69.2.61.60759

Miller, J., \& Doyle, B. A. (1987). Measuring the effectiveness of computer-based information systems in the financial services sector. MIS Quarterly, 11(1), 107-124. https://doi.org/10.2307/248832

Park, K., Lee, S. S., \& Khan, M. A. (2014). Exploring the impact of franchise support on franchisee acceptance of intranet in quick service restaurant (QSR) franchise system. Journal of Hospitality and Tourism Technology, 5(2), 143-159. https://doi.org/10.1108/JHTT-05-2013-0016

Phelps, R. \& Mok, M. (1999). Managing the risks of intranet implementation: An empirical study of user satisfaction. Journal of Information Technology, 14(1), 39-52. https://doi.org/10.1080/026839699344737

Rai, A., Lang, S. S., \& Welker, R. B. (2002). Assessing the validity of IS success models: An empirical test and theoretical analysis. Information Systems Research, 13(1), 50-69. https://doi.org/10.1287/isre.13.1.50.96

Reeves, C. A., \& Bednar, D. A. (1994). Defining quality: Alternatives and implications. Academy of Management Review, 9(3), 419-445. https://doi.org/10.5465/amr.1994.9412271805

Repack, D., \& Repack, W. (2010). A case study of the adoption and use of information systems technology in a business format franchise. Information Resources Management Journal, 23(1), 17-34. https://doi.org/10.4018/irmj.2010102602

Roberts, N., Galluch, P. S., Dinger, M., \& Grover, V. (2012). Absorptive capacity and information systems research: Review, synthesis, and directions for future research. MIS Quarterly, 36(2), 625-648.

Saleh, S., \& Kleiner, B. H. (2005). Effective franchise management. Management Research News, 28(2/3), 74-79. https://doi.org/10.1108/01409170510785110

Sirsat, S. S., \& Sirsat, M. S. (2016). A validation of the DeLone and McLean model on the educational information system of the Maharashtra State (India), International Journal of Education and Learning Systems, 1, 9-18.

Stefanović, S., \& Stanković, M. (2014). The Role of ICT and the Internet in the Development of Franchise Systems. Economic Themes, 52(4), 409-435. https://doi.org/10.1515/ethemes-2014-0026

Szajna, B. (1993). Determining information system usage-Some issues and examples. Information and Management, 25(3), 147-154. https://doi.org/10.1016/0378-7206(93)90037-T

Thompson, R. (2018). U.S. franchise restaurant industry: Spring 2018 update. Franchise Finance. Retrieved from https://commercial.bmoharris.com/resource/franchise-finance/2018-spring-franchise-restaurants/

Venkatesh, V., \& David, F. D. (2000). A theoretical extension of the technology acceptance model: Four longitudinal field studies. Management Science, 46(2), 186-204. https://doi.org/10.1287/mnsc.46.2.186.11926

Wahdain, E. A., \& Ahmad, M. N. (2014). User acceptance of information technology: Factors, theories and applications. Journal of Information Systems Research and Innovation, 6, 17-25.

Yap, C. S., Soh, P. P., \& Raman, K. S. (1992). Information systems success factors in small business. Omega, 20(5-6), 597-609. https://doi.org/10.1016/0305-0483(92)90005-R

Zheng, Y., Zhao, K., \& Stylianou, A. (2013). The impacts of information quality and system quality on users' continuance intention in information-exchange virtual communities: An empirical investigation. Decision Support Systems, 56(1), 513-524. https://doi.org/10.1016/j.dss.2012.11.008

\section{Copyrights}

Copyright for this article is retained by the author(s), with first publication rights granted to the journal.

This is an open-access article distributed under the terms and conditions of the Creative Commons Attribution license (http://creativecommons.org/licenses/by/4.0/). 